\title{
LA PINTURA MURAL DE GACAXTLA, TLAXCALA
}

Por Marta Foncerrada de Molina

En la primera mitad del mes de septiembre de 1975 fue descubierto, accidentalmente, en la zona arqueológica de Cacaxtla, en el suroeste de Tlaxcala, un extraordinario muro pintado cuyos elementos figurativos y dimensiones causaron asombro y un dejo de temor a los saqueadores. Comunicaron de su hallazgo a las autoridades civiles pertinentes y éstos a su vez lo reportaron al Instituto de Antropología. En unos pocos días los arqueólogos Daniel y Diana Molina, del Centro Regional de Puebla del Instituto Nacional de Antropología e Historia, iniciaron los trabajos de excavación en el montículo donde fue encontrado el mural. Se trata éste de un edificio habitacional que en época prehispánica fue rellenado por sus ocupantes. A las pocas semanas de trabajo arqueológico, en las que se despejó el escombro que rellenaba los muros del conjunto, se encontraron tres murales más y los restos incompletos de otro de mayor extensión en el muro posterior del único cuarto del pequeño palacio. Este importante mural fue cubierto, en época prehispánica, por un aplanado de lodo. Los tres murales del pórtico están extraordinariamente conservados en cuanto a sus valores de línea y de color porque los antiguos habitantes de Cacaxtla lo cubrieron cuidadosamente. Podría hasta decirse que fueron enterrados ritualmente, ya que no hubo intención por destruirlos: una gruesa capa de tierra suelta fue amontonada sobre la superficie de los muros y después de esta capa, el relleno consiste en piedras, tierra y tepetate. La capa de tierra suelta preservó casi en su integridad la calidad colorística y el diseño de los murales.

El edificio de las pinturas está constituido por un pórtico con una puerta al centro. A uno y otro lado de esta puerta central se encuentran dos murales de proporciones casi iguales. Cada una de las jambas de la puerta están decoradas también con pintura mural. En el muro posterior del cuarto, al que se accede por esta puerta central, aparece el mural de mayor extensión (figuras 1 y 2).

Las cuatro pinturas murales, a las que adscribimos una misma etapa de manufactura, muestran, sin embargo, un interesante proceso de parcial transformación que muestra una segunda fase de creatividad artística en el conjunto habitacional. Se trata del adosamiento, en los extremos de los dos murales del pórtico que colindan con la puerta, de un panel 
exquisitamente modelado en barro $(.45 \mathrm{~cm}$ de ancho $\times 1.79$ de alto, desde el arranque del piso). No se conserva in situ más que uno de los paneles, el otro se destruyó, pero dejó en el muro huella clara de su existencia y similitud de diseño con el que persiste. En ambos casos, el panel cubrió las secciones de mural que en forma idéntica contienen el hermoso diseño de una planta de maíz con mazorcas de abundante grano y planta trepadora con flores.

Por el interés que ofrecen los murales, no me detengo en el análisis artístico de los relieves de barro arriba mencionados. Simplemente señaló que se trata de un personaje sentado sobre un pedestal formado por dos mascarones superpuestos. El expresivo y enérgico rostro de perfil y la animada posición de manos y piemas le imprimen al personaje una particular vitalidad. La figura humana está inserta en un espacio exuberante por el abundante empleo de diseños ondulantes, como lo es, por ejemplo, el conjunto de elementos que conforman el complejo mascarón que le sirve de tocado al personaje (figura 3).

Antes de entrar en algunas consideraciones sobre la pintura mural de Cacaxtla, me parece pertinente citar a los arqueólogos Molina, en un primer reporte que hicieron sobre las características arquitectónicas del edificio que contienen los diseños pictóricos:

Hasta el momento se han podido identificar claramente tres etapas de construcción y están en estudio otras que se presentan con menos claridad. La primera detectada es el talud localizado en el norte del pórtico y que corresponde a una estructura de la que sólo conocemos el talud que está al sur de ella. A este elemento se añade un cuarto con una puerta en donde el talud sirve de pared norte. Más tarde se tapia la puerta, se amplía el cuarto en sentido norte-sur y se colocan unos muros en el interior que tienen como función crear un aspecto de simetría que, en realidad, no existe. Al centro se coloca una puerta que comunica el cuarto con el pórtico. En la parte exterior se colocan unos elementos con tablero y talud, que por sus propias características pasarán a engrosar la tipología del complejo tablero-talud; también estos adosamientos tienen por objeto crear la sensación de simetría, además de la nueva magnitud que con ellos adquiere el edificio, al que se le agregan dos pilares que se colocan alineados a los elementos mencionados. Ésta es la época en la que se pintan los murales, tanto en el interior como en el exterior. Todo el conjunto mencionado se encontraba sobre una plataforma con un desnivel promedio de $1.80 \mathrm{~m}$ con relación a la gran plaza que se encuentra al sur del conjunto. Posteriormente se rellena parte de este desnivel y se hace un nuevo cuarto adosado al anterior, creciendo el conjunto hacia el sur. 
Cacaxtla es un sitio arqueológico que en 1946 fue excavado por Armillas, quien hizo un reporte detallado de sus características urbanísticas y arquitectónicas. ${ }^{1}$ La característica que señala muy especialmente a este sitio es que se trata de una ciudad fortificada. La ciudad está rodeada por varios fosos de diversa extensión y profundidad y muestra muy objetivamente, como lo hacen algunas otras en el valle de Tlaxcala, la etapa de incertidumbre y asedio que vivió la región a la caída del Clásico. Sin embargo, el conjunto arquitectónico que contiene los murales parece ser anterior a las fortificaciones por la observación que Armillas hizo de pisos de estuco y de muros que fueron rotos al construirse los fosos. Armillas reportó que Cacaxtla fue un sitio ocupado por terrazas y montículos, una pirámide y una avenida situada en el lado este. Es interesante anotar que Armillas catalogó como pirámide precisamente el montículo que ahora, ya despejado del relleno que lo cubrió, conocemos como el edificio de las pinturas. Este edificio se prolonga hacia el sur en un cuarto con seis pilares al frente, el cual posiblemente fue rematado por una construcción de planta similar a la del edificio de los murales. Los muros y pilares de este edificio no estuvieron decorados con pintura mural figurativa. Un ancho zoclo pintado de rojo en el cuarto es el único elemento pictórico aún in situ en esta sección del palacio.

Todo el conjunto arquitectónico muestra varias etapas constructivas y restos de distintos elementos arquitectónicos y decorativos. El talud en el norte del pórtico del edificio de los murales pudiese señalar la existencia de una pirámide. Futuras excavaciones arqueológicas aclararán, sin duda, todas estas incógnitas.

La cerámica que Armilla encontró en Cacaxtla se encuentra también en Teotihuacán así como "otra que ocurre en Teotihuacán en fases tardias y que parece constituir un precedente del Coyotlatelco", 2 o sea la cerámica del periodo tolteca.

Los trabajos realizados por el arqueólogo Ángel García Cook, en la región de Tlaxcala, señalan que Cacaxtla pertenece en su aspecto ceremonial a la segunda mitad de las fase Tenanyecac: $100-650 \mathrm{~d}$. C., y en

1 Armillas, Pedro, "Los olmeca-xicalanca y los sitios arqueológicos del suroeste de Tlaxca'a". Revisla Mexicana de Estudios Antropológicos, t. vilr. Sociedad Mexicana de Antropologia. México, 1946, pp. 137-147.

2 Armillas, 1946, p. 144. 
su carácter de centro fortificado, a la fase Texcalac: $650-1100 \mathrm{~d}$. C." Desde un punto de vista estilístico, me inclino a pensar, por razones que expongo más adelante, que los murales de Cacaxtla corresponden aproximadamente a los siglos vin a $\mathrm{x}$ o sea, dentro del amplio y aún no claramente definido periodo Epiclásico, época en que los olmeca-xicalancas habitan la región de Tlaxcala.

\section{Los murales}

Como dije ya anteriormente los cuatro murales hasta hoy descubiertos decoran las dos paredes, a cada lado de la puerta central y las jambas de esta puerta que comunica al cuarto cuyo muro posterior también fue decorado con una escena pictórica. Pocas semanas lleva de iniciado el trabajo de limpieza de este mural parcialmente derruido, por lo que no es posible aún describirlo en su totalidad. Lo que hasta hoy se percibe del mismo es lo siguiente: al centro, un mascarón calavérico de pequeñas proporciones en posición frontal sobre el cual se desplanta un personaje jaguar del que únicamente se distingue una de las patas. A la derecha de este elemento central aparecen dos figuras humanas, visibles únicamente hasta la altura de la pantorrilla; la primera, pintada de negro, porta sandalias, la segunda, remata en garras de tigre. Los espacios vacios están parcialmente ocupados por apretado diseño de pequeñas serpientes entrelazadas. El diseño parece repetirse en forma similar al otro lado del mascarón. La composición del mural da un esquema en forma de paréntesis en el que los elementos convergen en el eje central del mural, el cual, a su vez, corresponde al de la puerta de acceso al cuarto. Los colores que actualmente son visibles son el rojo, el negro y un azul verdoso.

A pesar de que este mural se percibe aún muy incompleto puede leerse que por el esquema compositivo y por el número de figuras humanas que en él intervienen, pertenece al tipo pictórico denominado por Kubler como registro narrativo ${ }^{4}$ en el que está implícito un determinado contenido verbal cuyas implicaciones totales no podemos aún siquiera sugerir.

En relación a los murales del pórtico es necesario asentar que además

3 Garcia Cook, Angel, "Una secuencia cultural para Tlaxcala". Comunicaciones. Proyecto Puebla-Tlaxcala, núm. 10. Fundación Alemana para la Investigación Cientifica. Puebla, 1947, pp. 13 a 15.

4 Kubler, George, "Pintura mural precolombina". Estudios de Cultura Maya, vol. vi. Seminario de Cultura Maya, UNAM, 1967, p. 56. 
de la especial preminencia y riqueza decorativa que éstos le imprimen a una sección que sirve de acceso al espacio cerrado del conjunto habitacional, representan en sí mismos un complejo iconográfico excepcional en el arte pictórico prehispánico del Altiplano Central.

En Teotihuacán tenemos ya el importante antecedente de pórticos en edificios pequeños que estuvieron ricamente decorados con pintura mural. Sin embargo, lo que caracteriza y distingue a Cacaxtla de la expresión artística teotihuacana es la prevalencia en los cuatro murales de la figura humana aislada. Efectivamente, en Cacaxtla cada uno de los cuatro murales está compuesto por un personaje ricamente ataviado independiente de los otros tres, aunque indudablemente ligado a ellos simbólicamente. El atavío y los demás motivos que acompañan a cada uno de ellos son varios, distintos en su mayoria para cada mural y apuntan, a primera vista, a representaciones que muestran un nivel de sincretismo cultural en el que se presentan símbolos y patrones de diseño de diversas regiones de Mesoamérica, aún no relacionadas temporalmente con suficiente exactitud. Así, pues, dos de los personajes tienen un claro perfil maya, además de portar sendas barras ceremoniales, símbolo del poder tradicional de los hombres de esta cultura, mientras que los otros dos muestran rostros que aluden a un grupo étnico distinto, posiblemente el de la localidad. Alrededor de cada uno de los personajes y de manera particular, libre e imaginativa, se suceden motivos iconográficos teotihuacanos, glifos a la manera de Xochicalco, símbolos de la escritura mixteca, formas reminiscentes de Monte Albán y de Tajín (figuras 4, 5, 6 y 7 ).

El esquema colorístico de los murales es extraordinario. La intensidad de los colores y la calidad del pigmento mismo están preservados, casi intactos. En los dos murales del pórtico, las figuras humanas y los demás símbolos se insertan en un espacio pintado de rojo quemado, mientras que las figuras de las jambas están en un fondo azul, lo que produce un vívido constraste entre colores cálidos y colores fríos. El azul fue un color indudablemente gustado por el pintor de Cacaxtla, ya que predomina en detalles ornamentales y en símbolos; destaca particularmente la serpiente azul, cuyo emplumado cuerpo se extiende a los pies del personaje de perfil maya, en el pórtico, y se yergue a manera de columna a un lado de él; colores como cafés, ocres, rojos, naranjas, blancos, negros, amarillos rosas y verdes muestran la rica paleta que fue usada para caracterizar los numerosos detalles que integran cada 
una de las representaciones. El dibujo muestra por otra parte, el trazo fino y seguro de una mano de pintor experto que delineó imágenes con sutil precisión y amplitud de trazo para dar riqueza decorativa a las formas. Su sensibilidad de artista le permitió manejar con acierto las proporciones de la figura humana, al mismo tiempo que establecer correspondencias armónicas entre los numerosos elementos que componen el espacio pictórico.

Las característiças iconográficas y estilísticas de estos murales le proponen al investigador moderno una serie de incógnitas que son un reto rivo a su capacidad para reconstruir el pasado. Un amplio programa de investigación requiere, indudablemente, el estudio de la pintura mural de Cacaxtla. Investigación en la que participen arqueólogos, historiadores e historiadores del arte, para dilucidar el problema que plantea este extraordinario hallazgo.

Me limitaré a señalar en el presente artículo algunos de los aspectos que me parece indispensable mencionar para intentar reconstruir histó* rica y estilísticamente el extraordinario conjunto pictórico de Cacaxtla. Me parece fundamental establecer el carácter regional que esta expresión artística tiene antes de buscar lo que la relaciona o asemeja con otras de Mesoamérica. Es así que, a mi juicio, Cacaxtla representa, dentro de la tradición pictórica del Altiplano, un caso único. Esencialmente en nada se asemeja a Teotihuacán o a Cholula y si la pintura de estos dos sitios muy poco tienen en común, ahora con la de Cacaxtla tenemos un tercer sitio en las tierras altas del Valle Central que se revela con un estilo artístico de aparente desarrollo local sin mostrar estilística o temáticamente relación directa con la de estas dos ciudades antes mencionadas.

En el patrón de expresión artística del Altiplano, Cacaxtla es el primer caso en el que la pintura mural escoge a la figura humana de corte naturalista como el motivo iconográfico prevalente.

Desde el punto de vista de la escala, las cuatro figuras humanas tienen las siguientes medidas:

Mural del hombre-pájaro en el pórtico: $1.30 \mathrm{~m}$ sin tocado. Mural del hombre-jaguar en el pórtico: $1.33 \mathrm{~m}$ sin tocado. Mural del hombre-jaguar en la jamba: $1.12 \mathrm{~m}$ sin tocado. Mural del hombre danzante en la jamba: $1.08 \mathrm{~m}$.

Este conjunto de medidas difiere básicamente del utilizado por la 
gran pintura de Teotihuacán o de Cholula, porque en Cacaxtla la figura humana tiene proporciones que la acercan más a la del modelo natural.

De acuerdo con lo anterior puede decirse que en Cacaxtla es evidente el deseo del artista por destacar individualmente, por singularizar a cada una de las figuras humanas y caracterizarlas de acuerdo con un sistema particular en cada caso, no sólo de proporciones sino también de formas en el atavio, en un esquema compositivo en el que aparecen animales míticos, glifos y otros símbolos.

No existe en Cacaxtla el ritmo repetitivo e impersonal que asume la figura humana en Teotihuacán, ni la sucesión expresiva y dinámica de numerosos seres en diversas posturas y actitudes de los registros pictóricos en el llamado Mural de los Bebedores en Cholula. En Cacaxtla la intención artistica es de tipo presentativo, es una búsqueda consciente de la unicidad del ser humano, lo que, a mi juicio, implica una conrepción del hombre distinta a la que propone la pintura mural de Teotihuacán o de Cholula.

En los murales del pórtico, y en las jambas, desde el punto de vista de la composición, el esquema se asemeja al de un gran tapiz adherido al muro encuadrado por el o los marcos que, en cada caso, limitan el diseño pictórico del que destaca preminentemente la figura humana. La riqueza colorística y la fluidez y versatilidad del trazo lineal suaviza la dura línea del perfil arquitectónico y anula la sólida pesantez del muro. Esto se hace patente en la evidente continuidad del diseño que unifica compositivamente la pintura del muro del pórtico con la de la jamba a formar un todo perfectamente integrado.

El patrón compositivo de la pintura mural de Cacaxtla no es ajeno al de Teotihuacán. La originalidad del de Cacaxtla se manifiesta precisamente en lo anteriormente expuesto. En Teotihuacán, por ejemplo, cuando el recurso plástico fue, en la pintura de muros, la figura humana, ésta se redujo en escala o se repitió en composiciones de fría e impersonal simetría. El espacio pictórico, por otra parte, se fragmenta y subdivide en numerosas secciones. El espacio pictórico en los murales de Cacaxtla está enriquecido con elementos zoomorfos o glíficos, pero éstos giran como satélites en un orden medido en torno a la figura humana, el elemento primordial y más significativo de toda la composición.

Los cuatro murales, de acuerdo con las características arriba mencionadas, no corresponden a ninguno de los cinco sistemas pictóricos 
en los que Kubler dividió las expresiones artísticas de la pintura pre. colombina: frisos, procesiones, escenas, registros narrativos e ilustraciones. 5 Para la pintura de Cacaxtla cabría incluir un tipo más que, tentativamente denominó "simbólico-presentativo" caracterizado por la representación objetiva, sin visos de escenificación en la que la figura humana es el motivo prevalente, y alrededor de la cual se organizan diversos elementos iconográficos de variada connotación simbólica. La relación es, en este caso, de carácter ideológico, es eminentemente simbólica, no descriptiva de sucesos o acontecimientos relacionados con el acaecer histórico o con el relato mítico.

Lo anterior no invalida el que futuras investigaciones llegasen a adscribirle a estas figuras humanas una personalidad histórica especifica.

Me interesa destacar principalmente $y$, de acuerdo nuevamente con Kubler, ${ }^{6}$ el carácter nominal y adjetival de estas representaciones. En mi opinión, las figuras humanas en la pintura de Cacaxtla funcionan como nombres a los que califican indistintamente los demás elementos del diseño dentro de una jerarquización simbólica en la que los animales mf́ticos: la serpiente emplumada y el jaguar serpentino tienen, desde luego, un lugar preponderante.

La acción verbal en estas pinturas no está totalmente excluida, sino sutilmente señalada a través de los objetos que portan los personajes, como es, por ejemplo, que de una barra ceremonial caigan gotas de agua o de la vasija con la efigie de Tláloc que sostiene el hombre jaguar de una de las jambas se derrama el líquido vivificante o del caracol que sostiene en los brazos el danzante de la otra jamba, emerja el torso naturalista de un hombre de abundante cabellera. Estas expresiones verbales son las que, por otra parte, parecen indicar la significación simbólica, contenida en el conjunto pictórico, visto integralmente.

Respecto, a lo anterior, cabe reflexionar que la categoria de "pintura simbólica representativa", como he denominado a la de Cacaxtla, no tiene relación alguna con otras expresiones pictóricas de Mesoamérica. En cambio, la semejanza compositiva y temática sí puede establecerse con múltiples manifestaciones de la escultura, particularmente con los relieves en estelas mayas en las que la figura humana, la suntuaria y

5 Kubler, George, ibidem, p. 50.

6 Kubler, George, "The Iconography of the art of Teotihuacan". Studies in PreColumbian art and archaeology. Number Four. Dumbarton, Oaks. Trustees for Harvard University, Washington, D. C., 1967. 
otros motivos tienen, a mi juicio, el mismo carácter simbólico presentativo que el de las imágenes de Cacaxtla; lo simbólico presentativo, por otra parte, no excluye, el carácter histórico que en numerosas estelas mayas tiene el personaje; su historicidad está dada principalmente en el texto jeroglífico, no en el contenido temático de la representación. Las composiciones escultóricas de los relieves en pilares de Tula y Chichén-Itzá podrían encajar también dentro de esta clasificación.

Una de las incógnitas primordiales, con respecto a los murales de Cacaxtla, es preguntarse sobre el sustrato cultural que determinó un tipo de expresión tan original, de tan alta calidad artística, sin antecedentes en la región y sin solución de continuidad, hasta hoy conocida, en el Altiplano Central; pintura en la que se conjuga una simbología que, en cuanto a su procedencia, señala a varias regiones de Mesoamérica.

No es mi intención, en esta presentación, extenderme en un análisis extenso y complicado sobre los modelos que en el área maya existen para establecer su correspondencia con las representaciones de Cacaxtla, ni tampoco en la consideración de los motivos no mayas de las pinturas y sus relaciones con otros sitios de Mesoamérica. Éste será motivo de un amplio y sistemático estudio que deberá apoyarse en el que haga la investigación arqueológica sobre el sitio. Es así que las ilustraciones del artículo servirán como un primer elemento de incentivo visual para que el lector vea por sí mismo la riqueza iconográfica que esta manifestación artística posee y al mismo tiempo aprecie la maestría lineal y colorística con que fueron pintados cada uno de los elementos que integran los murales.

En el presente trabajo me interesa destacar el carácter local de esta manifestación artística sin antecedentes ni consecuencias ulteriores en el arte del Altiplano Central. Asentar que el sincretismo figurativo y simbológico de los murales apunta a un periodo de creatividad que, a mi juicio, rebasa el que corresponde al Clásico y parece pertenecer a los inciertos siglos entre la caída de Teotihuacán, el apogeo de Xochicalco y el inicio de la hegemonía tolteca. Si en el arte de Xochicalco hay evidencia absoluta de la influencia maya la posibilidad de la presencia de esta cultura en Cacaxtla no resulta ya tan incomprensible. A esta situación corresponden otras en Mesoamérica, como Tajín o el surgimiento del poderío mixteco que determinaron, contando con la individualidad genial del artista, con un momento estilístico que podría llamarse manierista en cuanto a lo que éste tiene de arte derivativo, 
pero también manierista en cuanto puede ser considerado como un transformador original de formas convencionales del pasado y como un forjador de nuevos patrones de expresión artística.

La ciudad de Cacaxtla tuvo una importancia estatégica especial. Armillas dice al respecto:

Desde Cacaxtla y desde Xochitecatl se domina hacia el sur todo el valle de Puebla, el de Tlaxcala, hacia el norte. Las lomas donde fueron construidos los centros dominan los valles de Atoyac y Zahualpa, caminos naturales de invasión de Tlaxcala por el sur y el sureste. ${ }^{7}$

A mi juicio, esta peculiar situación geográfica hizo posible durante el Epiclásico que los grupos humanos asentados en Cacaxtla transforniaran su legendaria tradición cultural derivada de la teotihuacana por la absorción de nuevas influencias llegadas del sitio a través de fuentes naturales de comunicación, las que en siglos posteriores volverianse amenazantes, determinarian la construcción de fortificaciones y cambiarian el orden social que los murales reflejan, por otro de sello militarista.

Asumo, que durante el Epiclásico, Cacaxtla vivió un corto periodo de paz y prosperidad que determinó la ejecución de construcciones decoradas con pintura mural; pintura que refleja un orden social que difiere del de Teotihuacán porque no posee el carácter eminentemente religioso del de la metrópoli. Este orden social de Cacaxtla, a la vista de su pintura mural, es menos sacro, revela un cierto grado de secularización y de apertura estilística, cuyo origen puede estar en el contacto que este sitio de Tlaxcala tuvo con los patrones artísticos y culturales de regiones distantes, particularmente la maya en cuanto a la importancia que en ésta tiene la figura humana. Una investigación más amplia sobre la iconografía de los murales deberá mostrar si en el rico mosaico de símbolos que ostenta cada uno de los murales puedan ser algunos considerados como creaciones formales originales o si, por el contrario, son formas localmente transformadas en conjuntos iconográficos nuevos.

Es mi opinión que, la pintura mural de Cacaxtla representa en Me. soamérica una expresión regional original, de gran vitalidad plástica, en la que se percibe la sólida fuerza de la tradición, pero también el arriesgado espíritu del innovador.

7 Armillas, 1946, p. 142. 
DOI: http://dx.doi.org/10.22201/iie.18703062e.1976.46.1055

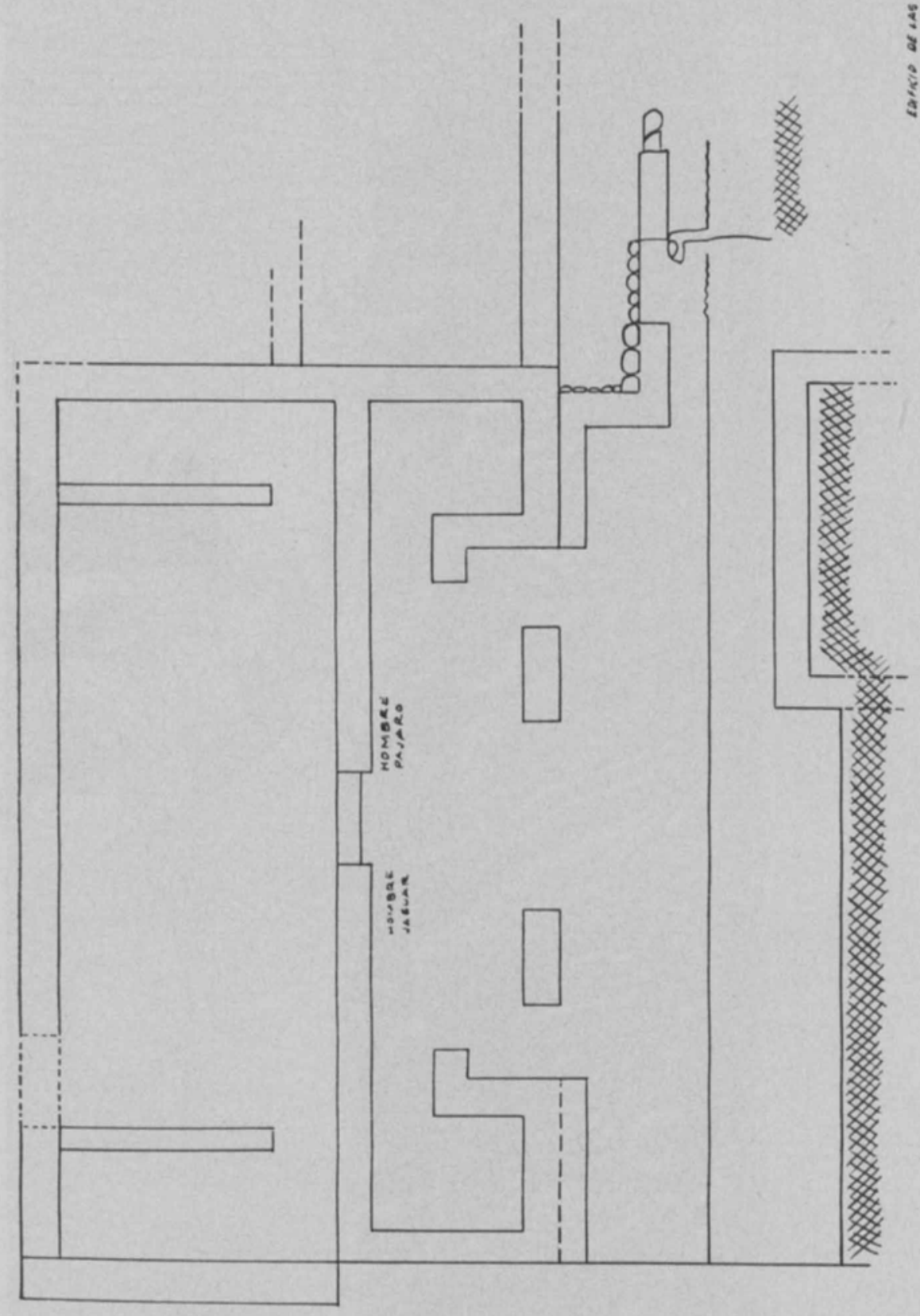



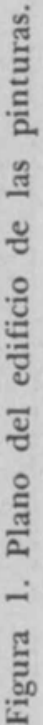


DOI: http://dx.doi.org/10.22201/iie.18703062e.1976.46.1055

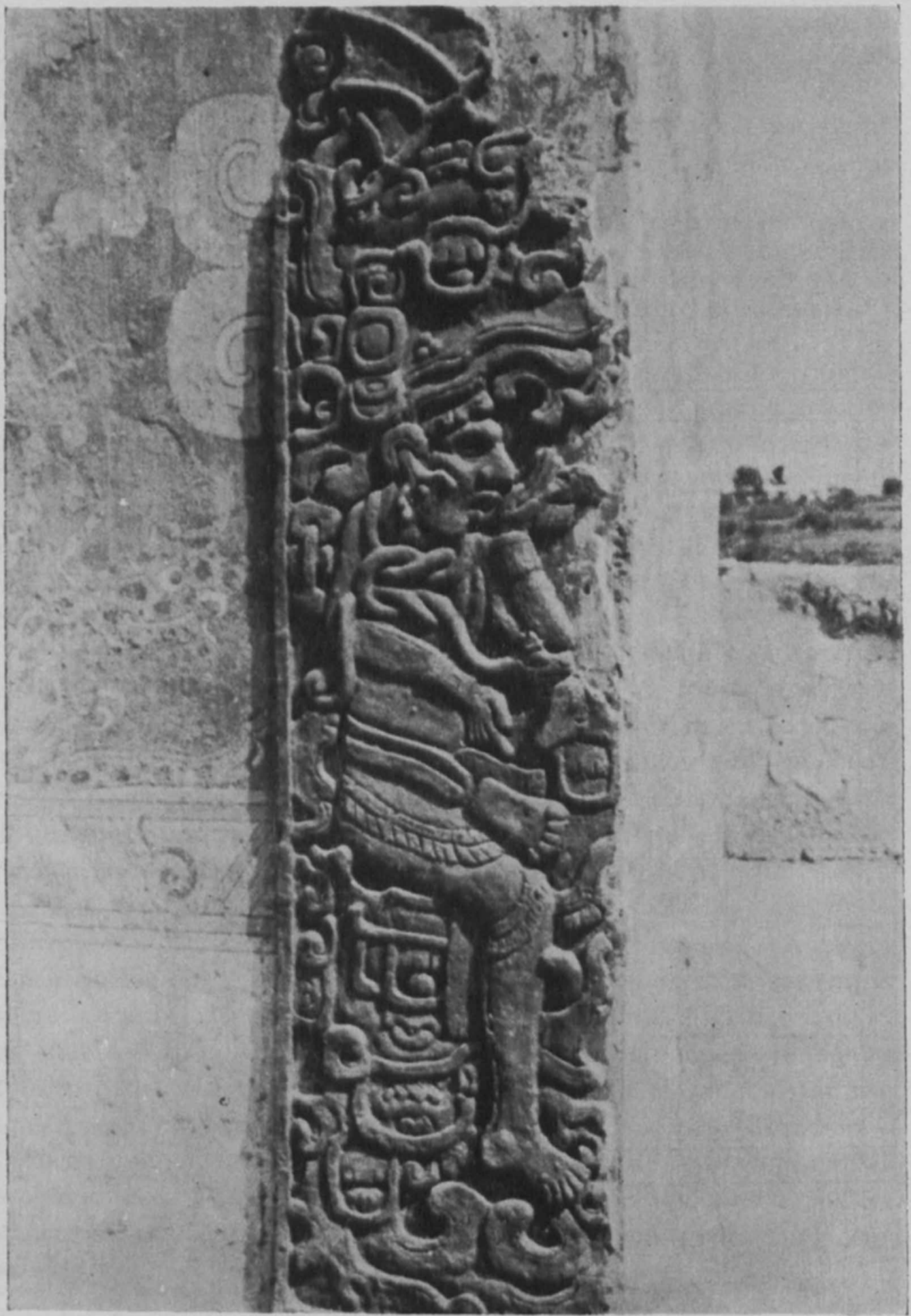

Figura 2. Relieve de barro en el pórtico. 
DOI: http://dx.doi.org/10.22201/iie.18703062e.1976.46.1055

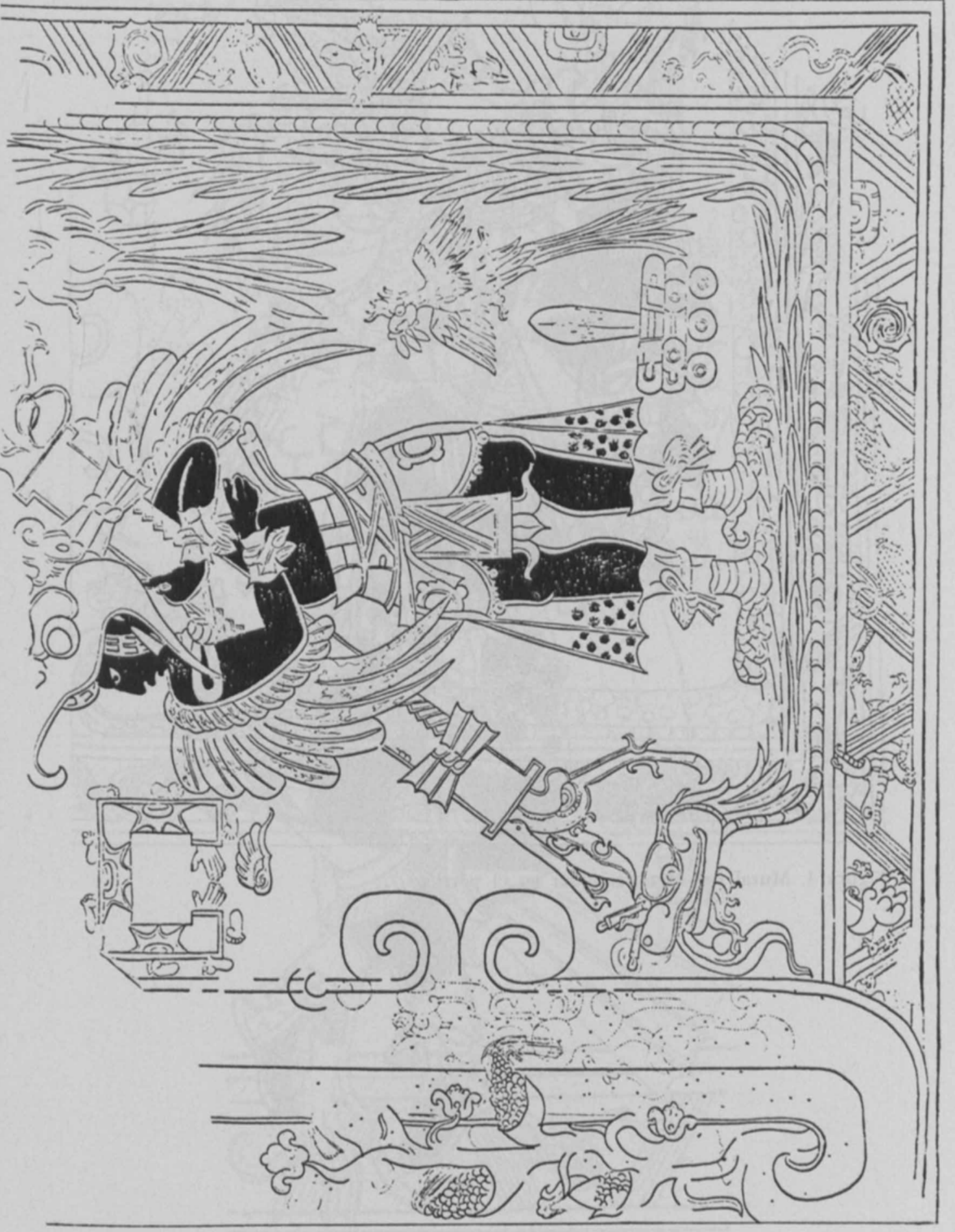

8. 


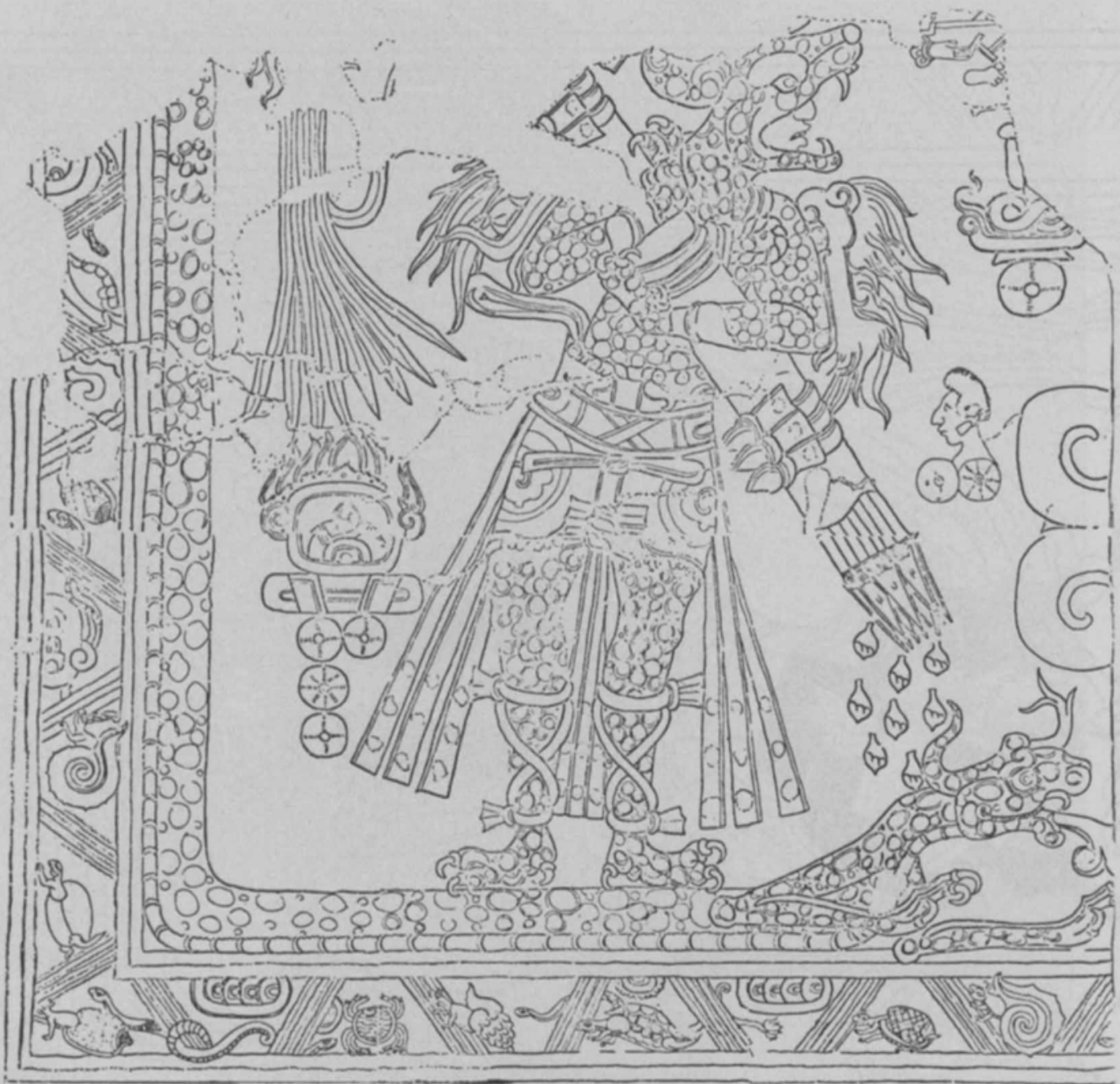

Figura 4. Mural del hombre-jaguar en el pórtico 
DOI: http://dx.doi.org/10.22201/iie.18703062e.1976.46.1055

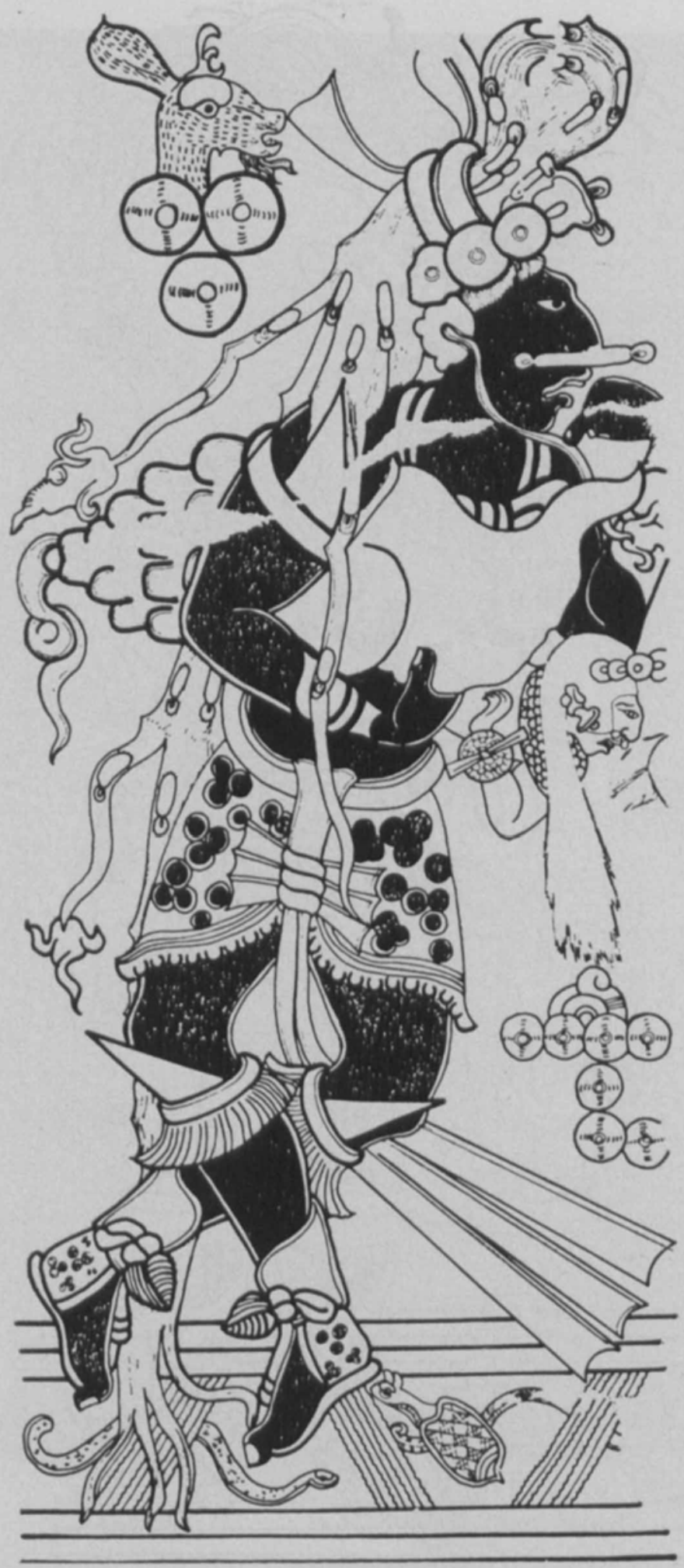

Figura 5. Mural de la jamba sur. 
DOI: http://dx.doi.org/10.22201/iie.18703062e.1976.46.1055

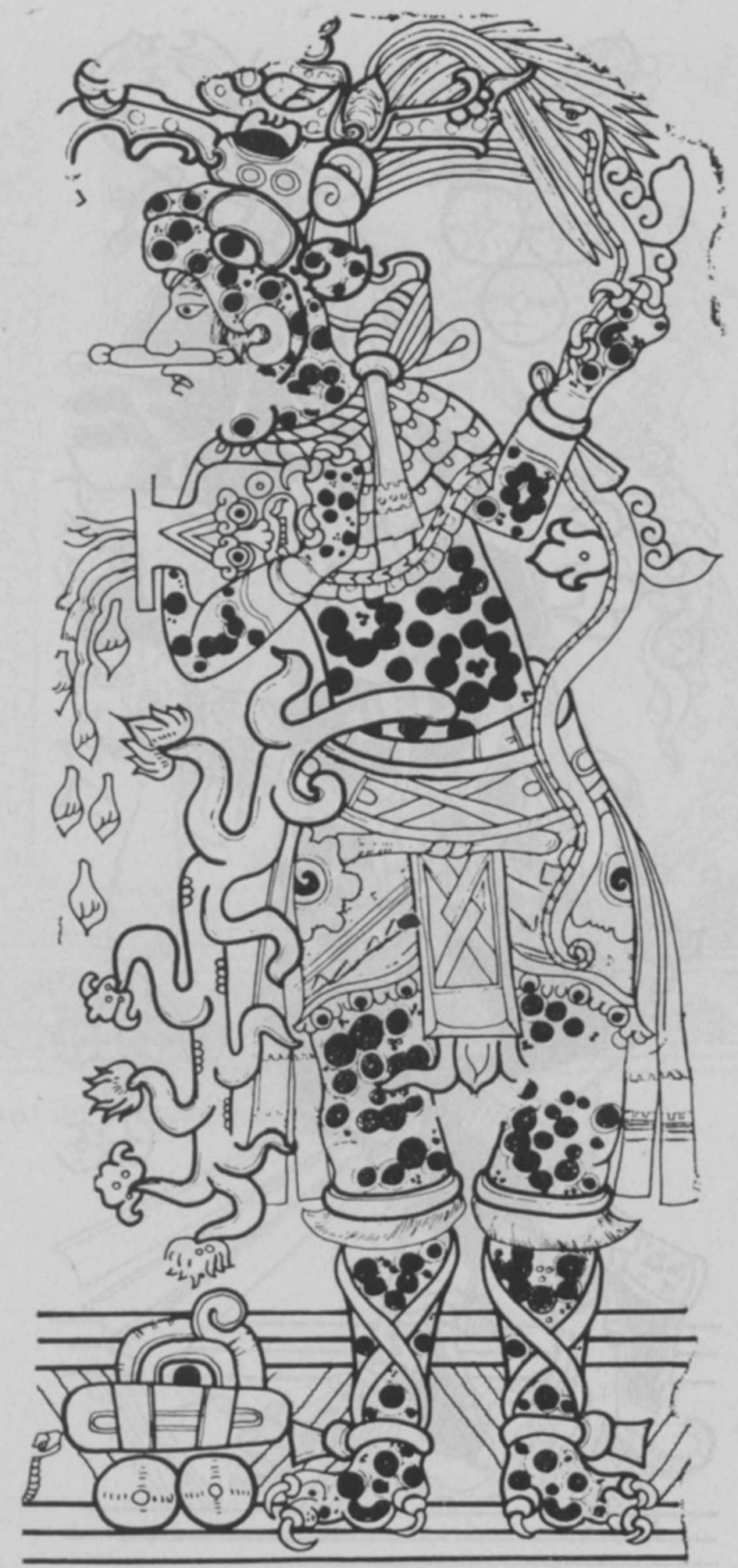

Figura 6. Mural de la jamba norte. 
DOI: http://dx.doi.org/10.22201/iie.18703062e.1976.46.1055

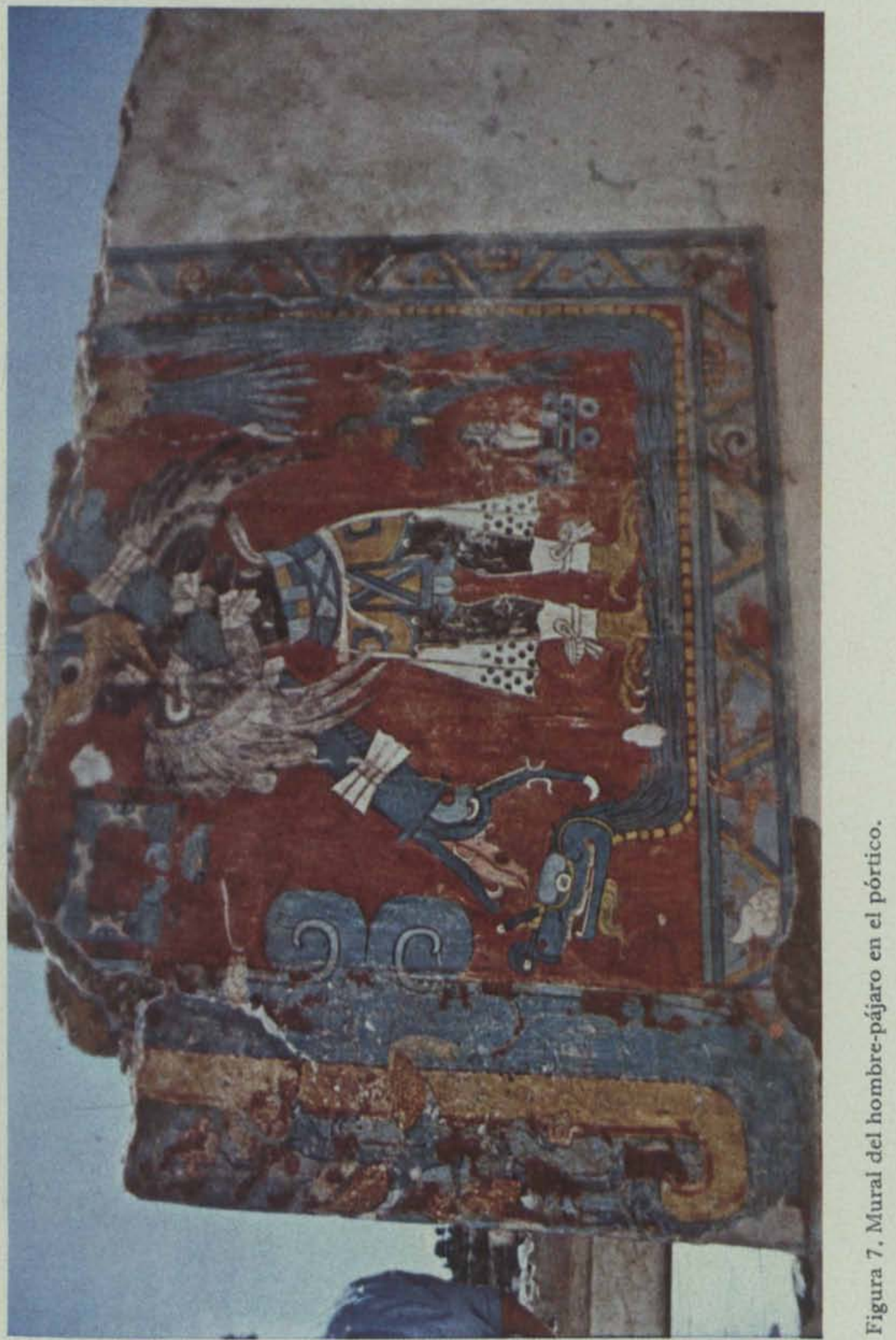


DOI: http://dx.doi.org/10.22201/iie.18703062e.1976.46.1055

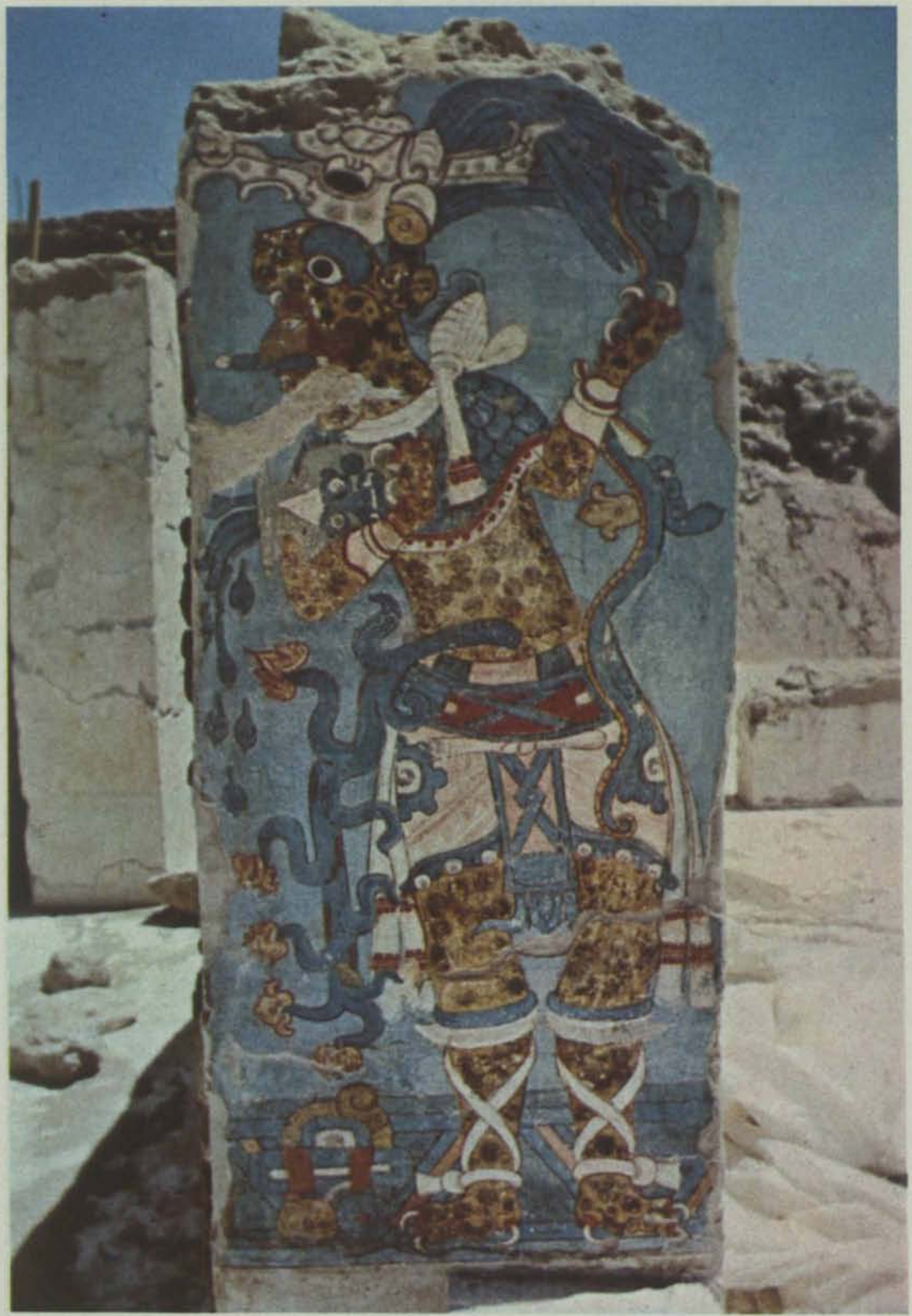

Figura 8. Mural de la jamba norte. 

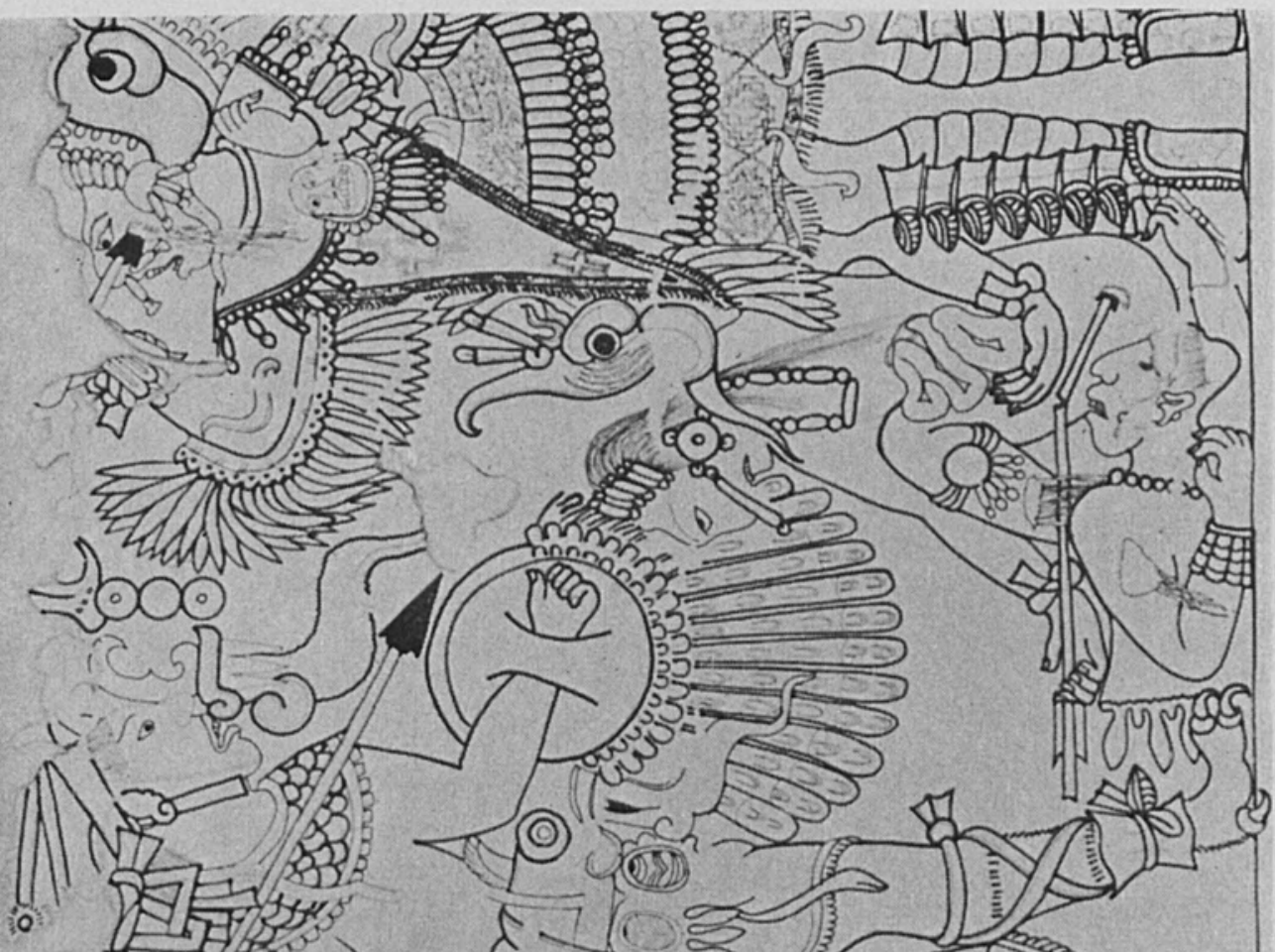
(1)

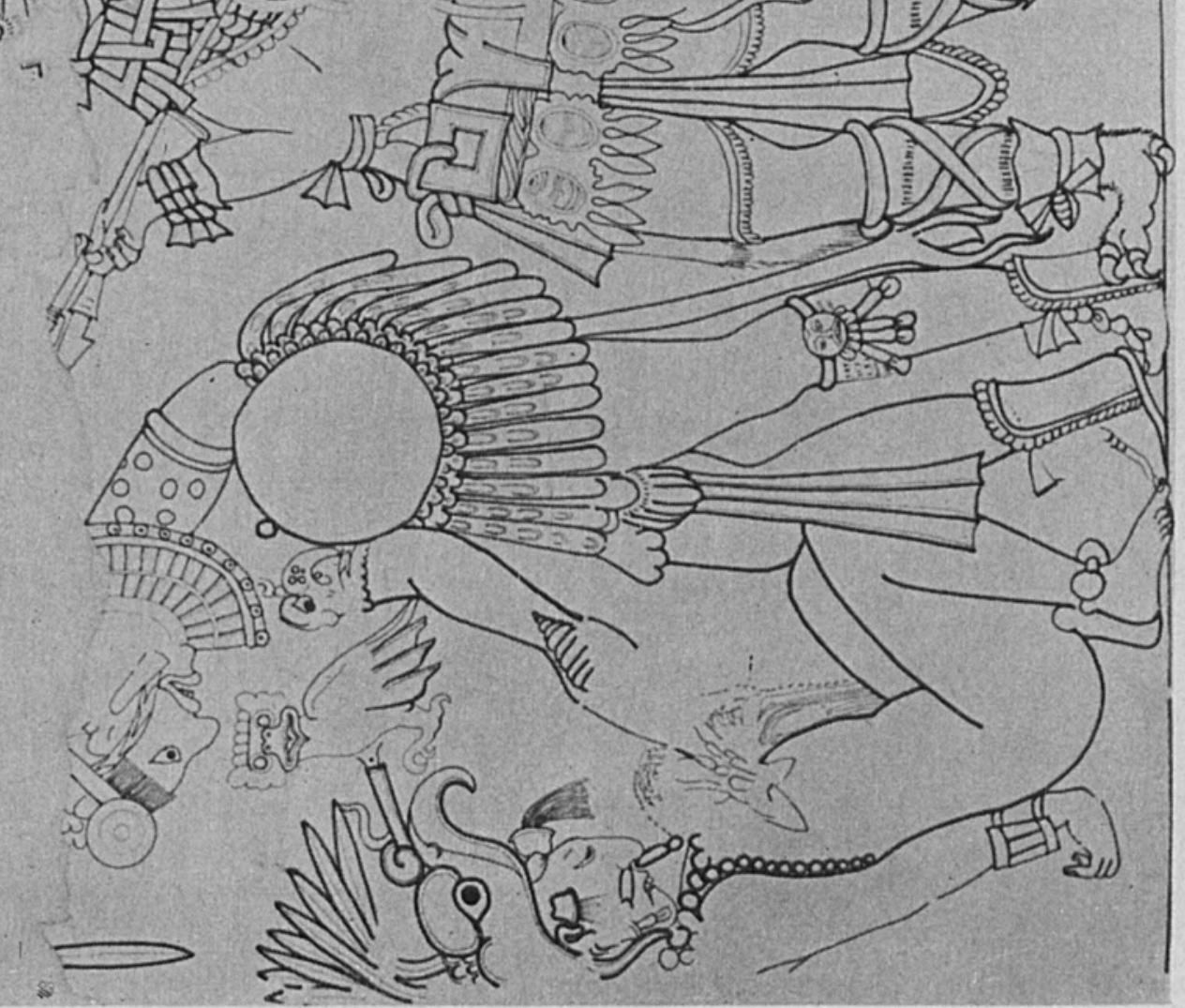

 
DOI: http://dx.doi.org/10.22201/iie.18703062e.1976.46.1055

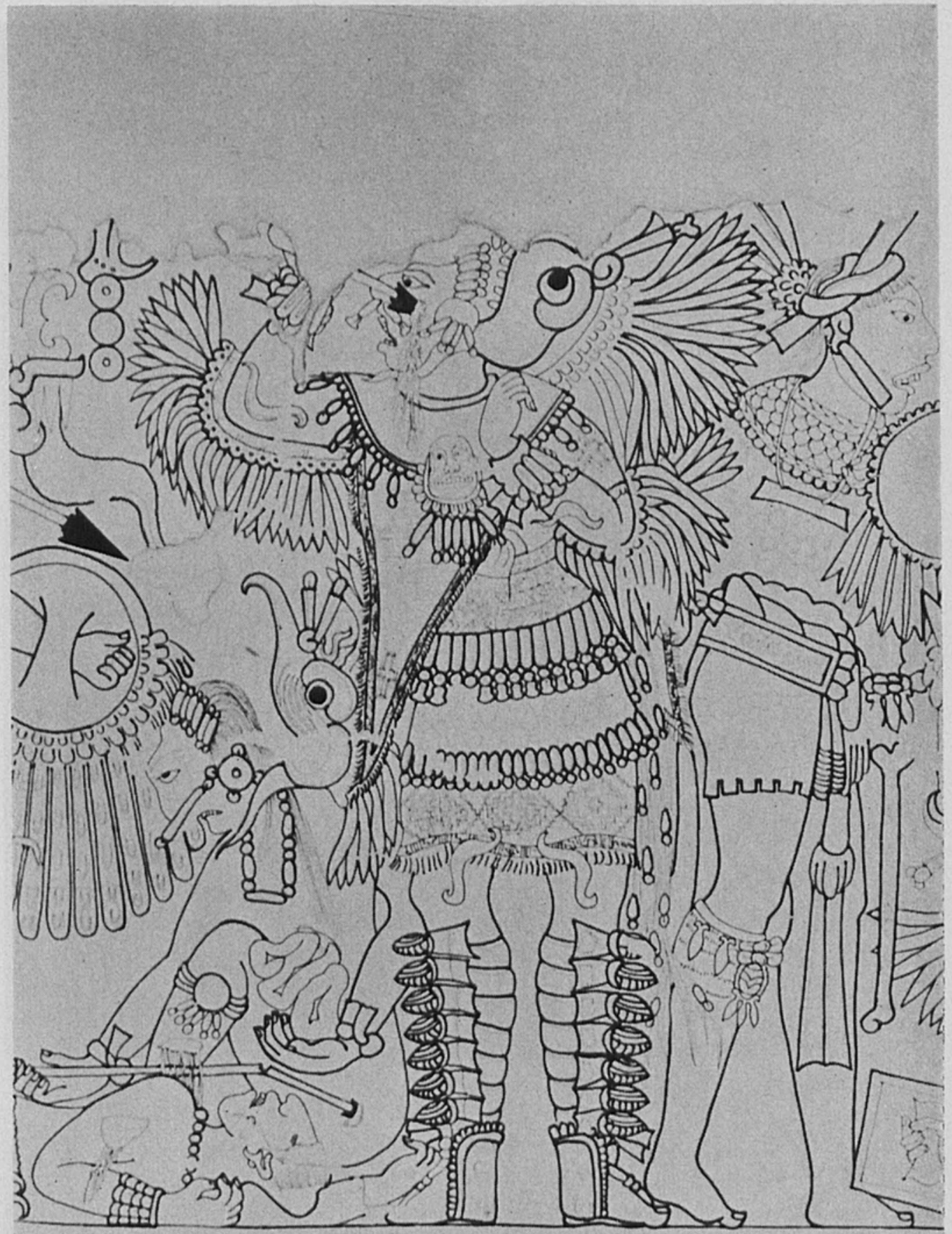

Figura 10. Mural de la guerra. Talud oriente. 
DOI: http://dx.doi.org/10.22201/iie.18703062e.1976.46.1055

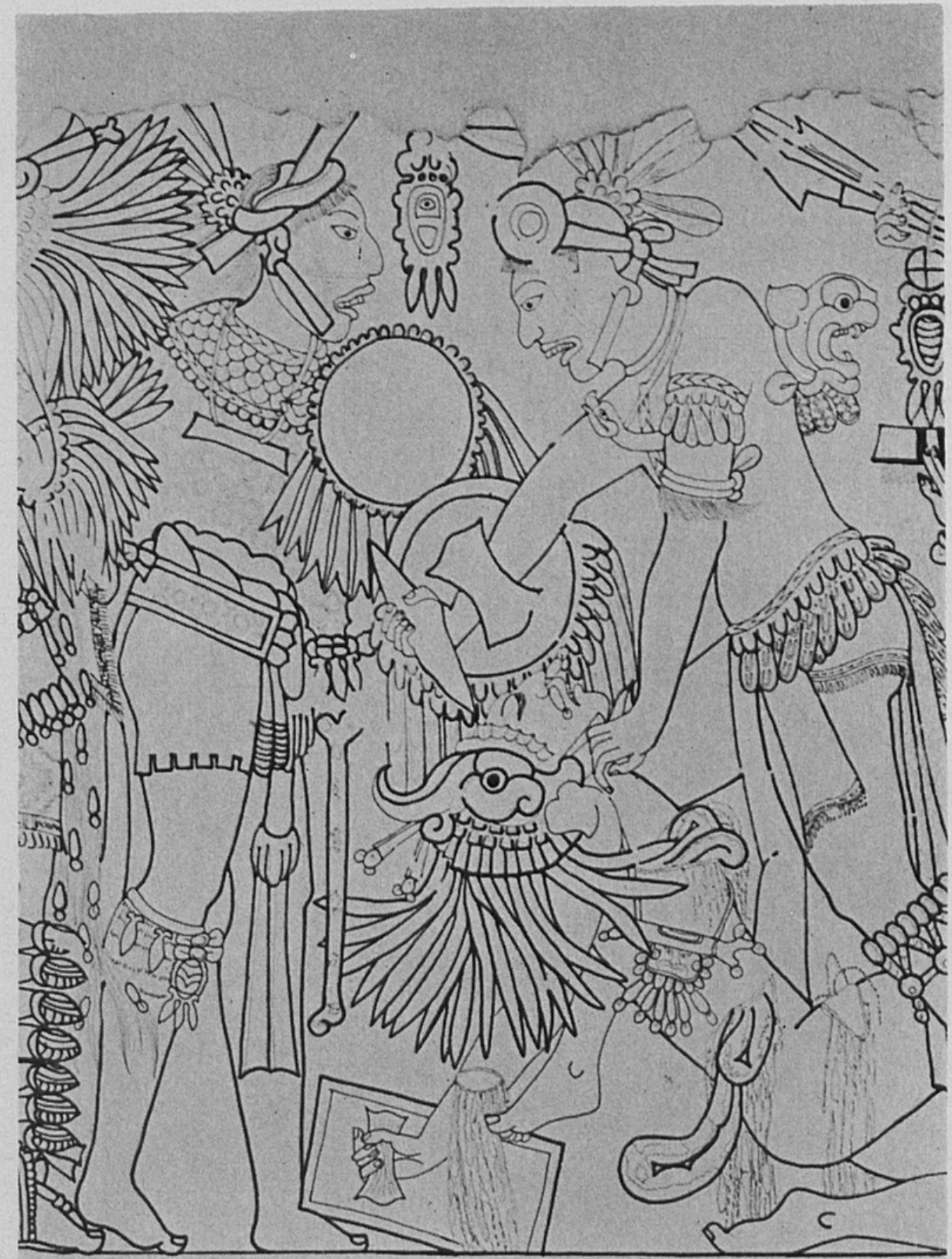

Figura 11. Mural de la guerra. Talud oriente. 
DOI: http://dx.doi.org/10.22201/iie.18703062e.1976.46.1055

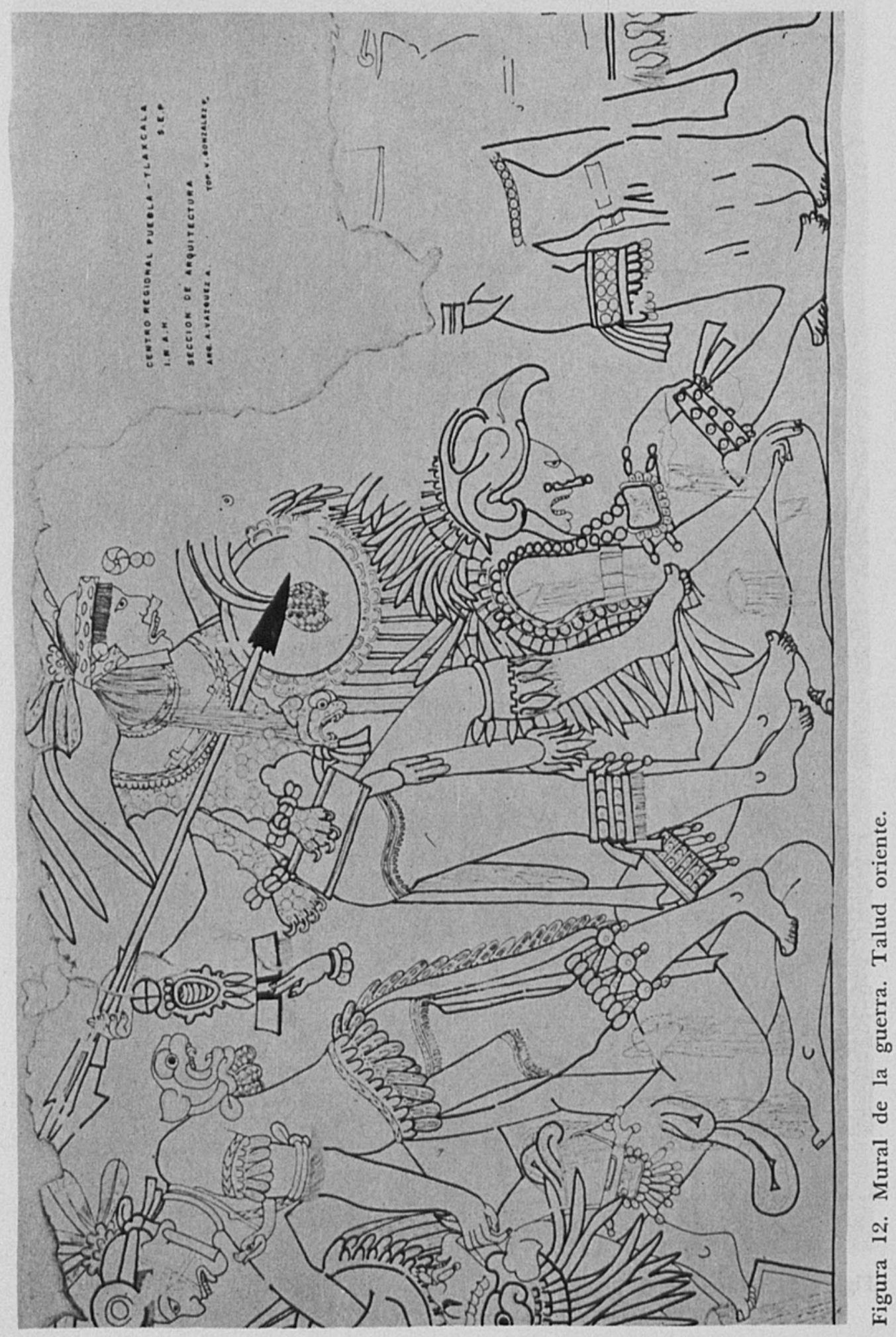




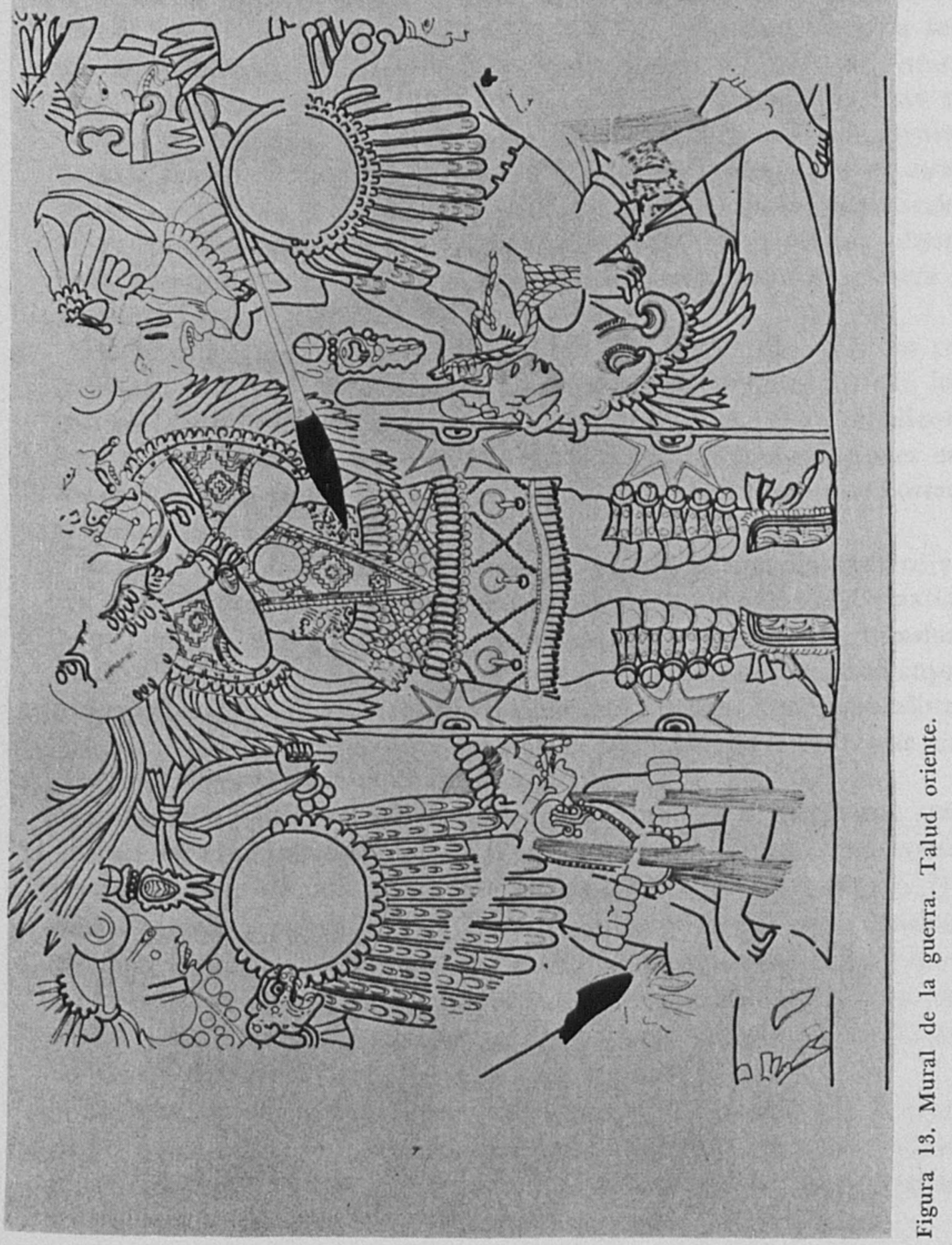


DOI: http://dx.doi.org/10.22201/iie.18703062e.1976.46.1055 
La originalidad artística que le confiero a Cacaxtla se basa en el supuesto de que el centro ceremonial no rebase temporalmente los límites del Epiclásico en el Altiplano. Asumo, pues, que Cacaxtla fue un centro ceremonial contemporáneo a Teotihuacán y que su pintura mural pertenece a la época en que éste pierde su hegemonía sobre el Altiplano, lo que permite que sitios como Cacaxtla pervivan dentro de una situación histórica nueva que los pone en contacto con otras regiones y que, en el caso especial de Cacaxtla, hace posible la creación de patrones estilísticos propios que, más tarde, serán a su vez, absorbidos y transformados por la cultura del Posclásico: tolteca, mixteca y mexica.

De acuerdo con lo anterior, me parece interesante relacionar las representaciones de hombre-pájaro y hombre-jaguar de Cacaxtla, con los que en la escultura mexicana más tardía conocemos como los caballeros águilas y caballeros tigre, y señalar las numerosas representaciones en los códices de la región Puebla-Tlaxcala de figuras humanas que portan disfraces de estos animales.

Es indispensable asentar que la imaginería arriba descrita aparece ya en Teotihuacán. La diferencia básica, con respecto a la de Cacaxtla, es que en ésta la escala de la figura humana fue esencialmente transformada en una búsqueda consciente que quiso plasmar imágenes cuyas proporciones corporales y rostros tuviesen un acusado trazo naturalista. Esta voluntad artística permite que apreciemos los rasgos étnicos que distinguen a unos personajes de otros.

Respecto al glifo cabeza de venado con numerales de punto, que aparece en el extremo superior del danzante en la jamba norte, considero que es un símbolo recurrente en los códices mixtecos (figura 7). Este elemento pictográfico en Cacaxtla parece preceder en el tiempo, al empleo sistemático que de él se hizo en las ilustraciones de los libros de la cultura mixteca, cuya antigüedad no es anterior al siglo xII de nuestra era, aunque posiblemente tengan tras de sí una tradición de varios siglos.

En relación al arte tolteca me parece interesante anotar que la gran serpiente de cuerpo emplumado, que rodea al hombre vestido de pájaro en el mural del pórtico, parece preconizar con su cuerpo que se yergue verticalmente, al diseño de las columnas serpentiformes de Tula.

Por otra parte, la presencia en Cacaxtla de símbolos de manos a la manera teotihuacana, el recuadro con animales acuáticos que enmarca 
los dos murales del pórtico, también reminiscentes de los de la pintura mural de Teotihuacán, como lo es, asimismo el pájaro de alas extendidas y larga cola al lado del hombre-pájaro; los glifos ojo de reptil en varios de los murales que son de ascendencia teotihuacana, pero también zapoteca, así como la serpiente emplumada, los glifos y los personajes mayas que asocian a Cacaxtla con Xochicalco o las implicaciones de dádiva acuática, de florecimiento de la naturaleza en agua que cae, en gotas y en flores, a la manera teotihuacana, revelan el raigambre cultural del sitio en tradiciones iconográficas que se encuentran desde el periodo Clásico.

De acuerdo a lo anterior, desde un punto de vista estilístico $y$, a reserva de todo lo que la información arqueológica pudiese reformar mi juicio, propongo considerar a los murales de Cacaxtla como expresiones de un arte provinciano original, en el que se desarrolló un estilo artístico local, vital y con gran coherencia interior. Estilo que, a mi parecer, nos permite percibir el genio individual de un artista $o$ tal vez de un taller local de pintura.

Las consideraciones anteriores apuntan al fascinante y poco estudiado problema de la individualidad en la creación artística prehispánica. F1 arte mesoamericano ha sido juzgado frecuentemente como un arte impersonal, en el que las formas artísticas son el resultado de un proceso ideológico concebido por la clase dirigente en el que el quehacer artístico casi se reduce a una mera actividad artesanal.

La pintura de Cacaxtla parece contradecir los supuestos arriba mencionados. EI tratamiento de las imágenes y el eclecticismo simbólico de sus formas me parece que debiera estudiarse desde la perspectiva de la individualidad, casi diría de la genialidad de un hombre o de una escuela de artistas a la luz de un arte esencialmente regional.

Es mi parecer que para un conocimiento más profundo del arte prehispánico, en general, debe siempre tomarse en consideración que las fronteras entre forma e idea en la obra de arte siempre han estado regidas por la potencia creadora de quien le da a la idea realidad física, las hace volumen, línea o color, las vuelve materia.

La sensibilidad del artista, indispensable para la existencia real de la obra de arte, entra precisamente en el intersticio que abre el juego entre la forma concebida intelectualmente y la forma realizada. Esta sensibilidad siempre es capaz de transformar, de enriquecer y aun de orientar el sustrato ideológico que toda obra de arte posee. 
En relación al problema específico de la pintura mural de Cacaxtla, me parece importante tomar en consideración que la caida de Teotihuacán significó, indudablemente, movimiento y reacomodo de pueblos, así como también movimiento de ideas. Este fenómeno debió servir como un fermento activador de creatividad artística que afectó varias regiones de Mesoamérica y en el que, a mi juicio, participó Cacaxtla durante el lapso de dos siglos, virI a $\mathrm{x}$, que comprende el Epiclásico.

El fenómeno del contacto cultural durante el Epiclásico se hizo más activo en regiones que como la de Cacaxtla fueron, en alguna medida, satélites de la cultura teotihuacana, en la época de su apogeo. Cacaxtla vivió durante el Epiclásico un periodo, el cual no podemos más que inferir por su producción artística, que la puso en relación con Xochicalco y el área maya, con la costa del Golfo y con la zona mixteca zapoteca, sin olvidar por completo su arraigo en la tradición iconográfica teotihuacana.

Interesa, sin duda, destacar la presencia maya porque durante el siglo viIr la cultura maya está aún floreciente, $y$, por orden de jerarquías, los personajes en los murales son más importantes que el resto de los elementos que componen cada mural. Pues bien, de los cuatro murales hasta hoy descubiertos, dos, tienen figuras humanas de claro perfil maya y en dos de ellos se encuentra asociada a los personajes una barra ceremonial de claro trazo mayoide.

En términos generales, respecto a las cuatro figuras humanas en cada uno de los murales parece que éstas son representativas de un tipo de hombre que se ajusta más al del periodo Clásico mesoamericano que al de épocas más tardías. En Cacaxtla tenemos un hombre vestido de ave y dos vestidos de tigre; el cuarto es un danzante, no disfrazado, que porta un enorme caracol del que sale un torso humano. Cabe, a mi juicio, considerarlos a los cuatro como personificadores de dioses, miembros de una sociedad que aún no pretende mostrar poderío militar, sino que los personajes, los elementos de la suntuaria y el tipo de simbología asociada a ellos están relacionados con los atributos divinos, con los que el hombre-sacerdote se invistió para desplegar sobre la comunidad su ascendencia y su poder civil y religioso.

Interesa apuntar, dentro de las muchas incógnitas que estas pinturas plantean, la pregunta sobre si se trata de representaciones impersonales de sacerdotes o de personajes reales con una específica connotación histórica. Las pinturas, por su carácter simbólico-presentativo tienen, a mi 
parecer, un aspecto heráldico que pudiese sugerir un tono impersonal que no hace alusión a hombres reales. Sin embargo, pudiese ser que este acento heráldico presente en la serpiente y en el jaguar serpentino bajo los pies, respectivamente, de las dos figuras del pórtico y varios de los otros símbolos religiosos y calendáricos que en ningún mural se repiten iguales, pudiesen indicar no sólo jerarquías de los personajes representados, sino su asociación expresa a comunidades y a rangos religiosos que bajo este tipo de diseño pictórico hubiesen querido dejar constancia de su status social y de su lugar de origen.

Por otra parte, y en apoyo a lo que asenté anteriormente respecto al sentido ritualista de las pinturas, considero que éstas esencialmente giran alrededor de conceptos de dádiva, de fecundidad de la tierra, de norecimiento y vida. Ideas todas éstas profundamente arraigadas en la concepción mesoamericana del mundo real. Impresiona, sin embargo, que en Cacaxtla este complejo religioso está tan profunda y novedosamente teñido de humanismo. La alusión al papel del hombre en el proceso transformador y generador de vida es absolutamente explícito y refleja, por sí mismo, cómo el artista de Cacaxtla quiso expresar estas ideas al posar a las dos figuras humanas del pórtico sobre los cuerpos yacentes de la serpiente y el jaguar serpentino, símbolos indudables de sol, lluvia y tierra, y dejar que de las barras ceremoniales, insignias del poder terrenal de la jerarquía, caigan gotas de agua, o que del cántaro que sostiene el hombre-jaguar de la jamba se derrame abundante corriente del líquido precioso o de su cuerpo surja una rama florida y que del caracol que sostiene el danzante, en la otra jamba, emerja un homḅre, símbolo también de nacimiento y vida. El sentido, pues, de los murales es de dádiva, no de los dioses, sino de hombres, poderosos, ricamente ataviados que con soberbia dignidad dejan constancia en unos muros de su poder como proveedores de lo que es más vital para la vida de la comunidad: el agua que activa la fuerza que yace en las entrañas de la tierra.

Para concluir estas reflexiones sobre uno de los hallazgos más sobresalientes y más intrigantes que ha dado, en los últimos años el arte prehispánico, puede decirse que la pintura de Cacaxtla representa un apasionante documento artístico que en sí mismo, aun sin conocer todas sus implicaciones históricas y estilísticàs, revela una vez más la capacidad del talento prehispánico para producir obras maestras. 
Después de entregado el artículo para su publicación, aparecieron otros murales de los que se da noticia a continuación.

En mayo de 1976 otro conjunto extraordinario de pintura mural fue descubierto por los arqueólogos Daniel y Diana Molina. Dichas pinturas constituyen la decoración del talud de una plataforma que sustenta el llamado Edificio B, localizado al suroeste del Edificio de las Pinturas. La construcción de dicha plataforma probablemente antecede en el tjempo al Edificio de las Pinturas por estar contruida en un nivel más bájo. El talud decorado con pintura mural está dividido al centro por una pequeña escalinata que sirve de acceso al Edificio $B$ el cual con siste en un pórtico orientado hacia el sur compueto por seis anchos pilares. El mural al oriente de la escalera mide $11.75 \mathrm{~m}$ de largo, el del lado poniente $8.43 \mathrm{~m}$ de largo. La altura del talud es de $1.55 \mathrm{~m}$. El impacto visual que producen estos 20 metros de pintura mural es verdaderamente extraordinario y en franco contraste con las representaciones del Edificio de las Pinturas. Se trata aquí de una extensa y compleja escena de guerra en la que se suceden aproximadamente cuarenta y ocho figuras humanas las más diversas posturas, actitudes y atavios. Es una representación eminentemente realista que muestra dramáticamente el enfrentamiento de dos grupos contendientes, en cuya lucha unos resultan vencidos y otros vencedores. Lanzas, escudos y cuchillos en manos de algunas de las figuras muestran al guerrero triunfante a cuyos pies $y$. adoptando las más diversas posturas aparecen los personajes derrotados mostrando, con excepcional crudeza, la huellas de su derrota en la sangre y aun las entrañas mismas que brotan de sus heridas.

Aparte de lo anterior distingue muy especialmente a un grupo del otro un elemento del atavío. Se trata del tocado, todos los personajes que sufrieron la derrota portan un yelmo de ave cuyas características: en el diseño lo relacionan con el del hombre-pájaro en el Edificio de las Pinturas; los vencedores por su parte muestran un tocado de lazos ceñido a la cabeza, plumas o flores, y en varios de ellos un elemento circular al frente. Por otra parte, la deformación craneana es evidente en el grupo de vencidos así como que los rasgos faciales de estos mismos sean más finos, los que se tornan toscos y agresivos en los vencedores; lo anterior permite suponer que la escena muestra una acción bélica entre dos grupos de filiación étnica distinta. 
Hasta ahora se han podido rescatar con precisión por medio de calcas las representaciones de diecisiete personajes de las cuarenta y ocho que se calcula contiene el talud en sus lados oriente y poniente. Existen en ambos murales secciones muy deterioradas, cuyo rescate será seguramente imposible. Sin embargo, puede decirse que se logra captar la significación total de la escena pintada ya que las imágenes, en su mayoría, las preservó de la acción destructora del tiempo, la enorme capa de tierra y piedras que por siglos las cubrió.

La sensibilidad artística del pintor o los pintores que realizaron los murales puede apreciarse a través del esquema coloristico que muestra con inusitada intensidad una paleta que combinó rojos con azules, blancos, negros, grises y amarillos en un dibujo de ágil línea que le dio forma a los cuerpos humanos en variadas posturas de excepcional dinamismo.

Los murales de la guerra nuevamente ponen de relieve lo que ya apunté respecto a los murales del Edificio de las Pinturas y que es el que deban considerarse como muestras importantes de creatividad regional. Nuevamente, a la luz de estas pinturas, Cacaxtla se revela como un foco de actividad artística donde la imaginación y el talento local de sus pintores se expresó fuera de los cánones tradicionales de la pintura teotihuacana, de la de Cholula, y aun de la maya. Sin embargo, la pintura misma revela la existencia del contacto cultural de Cacaxtla con estas áreas y con otras como Xochicalco, Monte Albán, Tajín y hasta lo Mixteco. Contacto que se expresa en muy diversos niveles, tanto en el de las formas artísticas y su jerarquía como en los símbolos y en la significación última de las representaciones, por lo que el problema del eclecticismo y del sincretismo en la pintura de Cacaxtla requiere de toda la información arqueológica que pueda recabarse sobre el sitio y su área, junto con el preciso y cuidadoso análisis de la iconografia y los valores estilisticos que las pinturas como formas visuales que documentan el pasado, muestran al espectador de hoy en día.

Las fotografias y dibujos que ilustran este estudio son cortesía del I. N. A. H. 